\title{
Section VIII: Civilians Participating in Unmanned Operations
}

\author{
Rule 75 \\ In the context of armed conflict-whether international or \\ non-international-civilians who conduct attacks using unmanned systems, \\ including RPA and UMS, are directly participating in hostilities.
}

\section{Commentary}

1. For a general comment on the notion of DPH in LOAC, see paragraph 1 of the Commentary to Rule 12 and chapter "Section VII: Civilians Directly Participating in Hostilities".

2. Attacks fall within the range of activities that unquestionably qualify as DPH. ${ }^{1}$

3. Although there may be legitimate debate over the point at which support for RPA operations (see Rule 44) — such as launch and recovery, maintenance and repair, input of data into control and target acquisition systems - amount to DPH, there is general agreement among the Group of Experts that actually controlling the aircraft during certain missions and/or executing lethal attacks constitutes DPH.

4. This Rule applies to any civilian, regardless of whether he/she has been authorized to accompany the armed forces. With regard to status upon capture, see Commentary to Rule 74.

5. The notion of DPH applies during all armed conflicts, whether international or non-international in character.

\footnotetext{
${ }^{1}$ Sandoz, Swinarski and Zimmermann (eds.), Commentary on the Additional Protocols of 8 June 1977 to the Geneva Conventions of 12 August 1949 (AP/I Commentary), (Geneva: Martinus Nijhoff Publishers) (1987), at page 619: "Thus direct" participation means acts of war which by their nature or purpose are likely to cause actual harm to the personnel and equipment of the enemy armed forces. It is only during such participation that a civilian loses his immunity and becomes a legitimate target."
} 
6. This Rule applies to civilians supporting State armed forces, to civilians associated with other State agencies or organizations (such as intelligence services), and to civilians supporting non-State organized armed groups.

\section{Rule 76 \\ To facilitate the implementation of the principle of distinction in an interna- tional armed conflict, States should refrain from authorizing civilians to engage in attacks using unmanned systems.}

\section{Commentary}

1. LOAC does not prohibit the use of civilians to engage in activities that qualify as DPH. However, LOAC does render civilians liable to be attacked for such time as they take a direct part in hostilities. To facilitate implementation of the principle of distinction, the Group of Experts recommended that States refrain from use of civilians engaging in activities that qualify as DPH.

2. Distinction between combatants (and/or members of armed groups) and all other individuals is facilitated when combatants effectively distinguish themselves from the civilian population. Such "passive distinction" measures facilitate the ability to make lawful versus unlawful attack decisions.

3. LOAC does not recognize any category of "quasi" combatant. When civilians are known by the enemy to be engaging in DPH, the protection afforded to other civilians not so engaging may be jeopardized. This may happen because innocent civilians may erroneously be assessed as engaging in DPH and thus may be subjected to attack. Accordingly, the Group of Experts recommended that States endeavour to limit civilian roles to those functions that do not qualify as DPH, such as operating RPAs in hostilities.

4. LOAC does not indicate or restrict the manner by which individuals may be incorporated into the armed forces. Instead, this is left exclusively in the hands of domestic authorities.

5. This chapter relates exclusively to the issue of protection from enemy attack. The separate issue of capture by the enemy of civilians who are engaging in DPH has little or no relevance to RPA operators who are usually placed at some distance from the theatre of operations.

Open Access This chapter is licensed under the terms of the Creative Commons Attribution 4.0 International License (http://creativecommons.org/licenses/by/4.0/), which permits use, sharing, adaptation, distribution and reproduction in any medium or format, as long as you give appropriate credit to the original author(s) and the source, provide a link to the Creative Commons licence and indicate if changes were made.

The images or other third party material in this chapter are included in the chapter's Creative Commons licence, unless indicated otherwise in a credit line to the material. If material is not included in the chapter's Creative Commons licence and your intended use is not permitted by statutory regulation or exceeds the permitted use, you will need to obtain permission directly from the copyright holder.

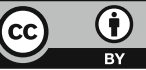

